\title{
САНАТОРНО-КУРОРТНА РЕАБІЛІТАЦІЯ ВІЙСЬКОВОСЛУЖБОВЦІВ В УКРАЇНІ: ПУБЛІЧНО-УПРАВЛІНСЬКИЙ АСПЕКТ
}

\section{SANATORIUM-RESORT REHABILITATION OF MILITARY IN UKRAINE: PUBLIC-ADMINISTRATIVE ASPECT}

УДК 351/354

DOI https://doi.org/10.32843/

pma2663-5240-2020.19.4

\section{Бабова І.K.}

д. мед. наук, старший науковий співробітник,

профессор кафредри проєктного менеджменту

Одеський регіональний інститут державного управління

Національної академії державного управління при Президентові України Рожков В.C.

д. мед. наук, старший науковий співробітник,

головний науковий співробітник Український науково-дослідний інститут медичної реабілітації та курортології Міністерства охорони здоров'я України у статті висвітлені особливості організації системи медико-психологічної та медичної реабілітації військовослужбовців у санаторно-курортних умовах в Україні проаналізовано, у яких санаторно-курортних закладах надаються відповідні послуги, їхн відомча підпорядкованість, норматив но-правові засади їх забезпечення; проаналізовано сучасний стан системи надання реабілітаційних послуг військовослужбовцям у санаторно-курортних умовах, узагальнено механізми публічного управління цією системою, зокрема організаційно-правового, економічного та ресурсного механізмів; розкрито сутність ресурсного механізму та проаналізовано його складові частини: структурно-технологічний, кадрові ресурси, інсоормаційні ресурси. Розкрито зв'язки між суб'єктом та об'єктом санаторно-курортної реабілітації та лікування, ії мета.

Основними проблемами організації санаторно-курортного лікування та реабілітації військовослужбовців в Україні є міжвідомча неузгодженість; значна розгалуженість санаторно-курортних та реабілітаційних закладів, які надають цей вид медичної допомоги, що ускладнює їхню підзвітність і аналіз ефективності лікування; відсутність єди них стандартів та необхідність оновлення чинних стандартів надання медичної та медико-психологічної допомоги в санаторно-курортних умовах.

Вирішення питань публічного управління системою медичної (психологічна, фізична) реабілітації та санаторно-курортного лікування військовослужбовців сприятиме впровадженню в національне законодавство міжнародних стандартів у сфрері реабілітації, удосконаленню системи надання реабілітаційних послуг (фрізична, медична, психологічна реабілітація) на етапі санаторно-курортного лікування та розвитку системи реабілітації в Україні, зниженню рівня інвалідизації військовослужбовців та скорішому поверненню до військової служби, покращенню якості їхнього життя, відновленню залишкової прачездатності ветеранів та поверненню ї до активного соціального та професійного життя.
Ключові слова: публічно-управлінський аспект, медико-психологічна реабілітація, санаторно-курортний етап, військовослужбовці, механізми публічного управління.

The article highlights the peculiarities of organization of medical-psychological and medical rehabilitation system of military in sanatorium-resort conditions in Ukraine; analyzed in which sanatoriums the relevant services are provided, their departmental subordination, regulatory framework for their provision; the current state of the system of providing rehabilitation services to military in sanatorium-resort conditions is analyzed and the mechanisms of public administration of this system are generalized, in particular organizational-legal, economic and resource mechanisms; the essence of the resource mechanism is revealed and its components are analyzed: structure-technological, personnel, information resources. The connections between the subject and the object of sanatorium rehabilitation and treatment, its purpose is revealed.

The main problems of the organization of sanatorium treatment and rehabilitation of military in Ukraine are interdepartmental inconsistency; significant branching of sanatoriums and rehabilitation institutions that provide this type of medical care, which complicates their accountability and analysis of the effectiveness of treatment; lack of uniform standards and the need to update existing standards for medical and medical-psychological care in sanatorium conditions.

Addressing the issues of public administration of system of medical (psychological, physical) rehabilitation and sanatorium treatment of servicemen will contribute to the introduction of national standards in the field of rehabilitation, improvement of rehabilitation system services (physical, medical, psychological rehabilitation) at the sanatorium stage, development rehabilitation systems in Ukraine, reducing the level of disability of military and early return to military service, improving their quality of life, restoring the residual capacity of veterans and returning them to active social and professional life.

Key words: public-administrative aspect, medical and psychological rehabilitation, sanatorium-resort stage, military, mechanisms of public administration.
Постановка проблеми в загальному вигляді. Чисельність Збройних сил України (далі - ЗСУ) визначена Закон України «Про чисельність Збройних Сил України» [1] у кількості, яка не перевищує 250 тисяч осіб, зокрема й 204 тисячі військовослужбовців. За даними Міністерства у справах ветера- нів, станом на 1 липня 2019 р. в Україні зареєстровано майже 370 тисяч осіб, які мають статус учасника бойових дій (далі - УБД) із числа осіб, які захищали незалежність, суверенітет і територіальну цілісність України та брали безпосередню участь в антитерористичній операції (далі - АТО), забезпеченні її 
проведення; щороку збільшується кількість військовослужбовців, які мають статус особи з інвалідністю внаслідок бойових дій: у 2019 р. налічувалося майже 11 тисяч ветеранів, тоді як у 2018 р. - приблизно 3 тисячі [2]. Кількість цивільних осіб, які зазнали поранення, станом на 2018 р. становить 1151 [3].

Нині ці громадяни потребують належної уваги до себе з боку держави та надання їм відповідних соціальних гарантій. Основні засади державної політики у сфері соціального захисту військовослужбовців відповідно до Конституції України визначено Законом України «Про соціальний і правовий захист військовослужбовців та членів їх сімей» [4], який встановлює єдину систему соціального та правового захисту, надає військовослужбовцям та членам їхніх сімей комплекс гарантій.

Військово-медична галузь, зокрема система медичної та психологічної реабілітації, - не менш важливі сфери реформування оборонного сектора, ніж забезпечення армії сучасним озброєнням, налагодження системи органів військового управління, логістики та кадрового менеджменту за натовським взірцем. У Річній національній програмі під егідою Комісії Україна - НАТО на 2020 р., затвердженій Указом Президента України від 26 травня 2020 р. № 203/2020 [5], зокрема у стратегічній меті 2.4 «Об'єднані система логістики і система медичного забезпечення здатні надавати підтримку усім складовим сил оборони», наголошено необхідність міжвідомчої взаємодії медичних служб сил оборони, системи охорони здоров'я та військово-медичної освіти, що має досягатися шляхом визначення єдиного органу сил оборони, відповідального за координацію оборонних питань у галузі медичного забезпечення; розроблення та затвердження єдиних стандартів медичної допомоги, клінічних протоколів та інших галузевих стандартів у сфері охорони здоров'я; створення єдиної інформаційної системи медичного забезпечення складових частин сил оборони, яка відповідає стандартам, доктринам та рекомендаціям НАТО; запровадження модульного підходу до створення системи надання медичної допомоги в рамках єдиного медичного простору сил оборони.

Результатом реформування та розвитку системи медичного забезпечення ЗСУ, на думку О. Шекери, буде створення єдиного медичного простору; упровадження сучасної системи надання кваліфікованої та спеціалізованої медичної допомоги, лікування, реабілітації хворих за територіальним принципом; формування ефективної в економічному плані системи медичного забезпечення завдяки запровадженню медичного страхування всіх категорій військовослужбовців і працівників 3СУ [6, с. 270-271].

Саме залучення етапу санаторно-курортної реабілітації та лікування відповідає вітчизняним особливостям організації медичної допомоги, зокрема медико-психологічної та медичної реабілітації, а саме наявністю розгалуженої мережі санаторно-курортних закладів - курортів місцевого та державного значення різної форми власності та відомчого підпорядкування, зокрема так званих «силових» відомств (Міністерство оборони України, Міністерство внутрішніх справ (далі - МBC) України, Державної служби України з надзвичайних ситуацій (далі - ДСНС), Служби безпеки України (далі - СБУ), Державної прикордонної служби (далі - ДПС) України тощо). Реабілітація в санаторно-курортних умовах дозволяє комплексно лікувати психологічні порушення та супутні соматичні та психосоматичні (які виникли внаслідок подій, що завдали психотравми) патології, наслідки травм і поранень, отриманих під час виконання військових операцій.

Аналіз останніх досліджень і публікацій. Аналіз стану організації надання медичної допомоги, зокрема медичної, психологічної, фізичної реабілітації та санаторно-курортного лікування (далі - СКЛ) військовослужбовців в Україні, висвітлено в численних публікаціях вітчизняних дослідників, середих як: Я. Радиш, О. Соколова; Б. Мойса, О. Павліченко, О. Мартиненко; К. Бабов, І. Пінчук, В. Стеблюк; I. Назаренко, В. Якимець, В. Печиборщ, Г. Слабкий; О. Гавловський; І. Шевчук, М. Беляєва, О. Яворовенко, І. Куриленко.

Мета статті - вивчення механізмів публічного управління службою санаторно-курортної реабілітації військовослужбовців в Україні й аналіз наявних проблем управління цією системою.

Для досягнення мети поставлені такі завдання:

1. Проаналізувати мережу наявних в Україні реабілітаційних закладів, які надають послуги військовослужбовцям.

2. Здійснити аналіз нормативно-правових засад публічного управління в системі надання реабілітаційної допомоги військовослужбовцям в Україні.

3. Визначити механізми публічного управління системою санаторно-курортної реабілітації військовослужбовців в Україні та запропонувати шляхи вдосконалення її організації та публічного управління.

Виклад основного матеріалу. Однією 3 важливих соціальних гарантій, що надаються державною військовослужбовцям, $€$ надання 
медичної допомоги, зокрема й санаторно-курортного лікування та реабілітації в санаторних умовах (як суто медичної, так і медико-психологічної, за допомогою спеціалізованих реабілітаційних послуг), згідно зі ст. 11 Закону України «Про соціальний та правовий захист військовослужбовців та членів їх сімей» [4]. Порядок забезпечення СКЛ реґламентується постановою КМУ від 27 квітня 2011 р. № 446 (у редакції від 16 травня 2017 р.) [7].

Суб'єктами, які задіяні у процесі надання реабілітаційних послуг військовослужбовцям, виступають:

- по-перше, відомства, відповідальні за організацію та фінансування послуг: Міністерство охорони здоров'я (далі - МО3), міністерства соціальної політики, оборони й інші «силові» відомства, у справах ветеранів Україні;

- по-друге, надавачі медичних послуг: санаторно-курортні та реабілітаційні заклади різної форми власності та відомчого підпорядкування, приватні також;

- по-третє, відповідальні за підготовку фахівців для сфери реабілітації: Міністерство освіти і науки України, МОЗ.

Об'єктом є отримувачі послуг санаторно-курортної реабілітації: усі категорії військовослужбовців, ветеранів, членів їхніх сімей, які потребують реабілітації, медичної, психологічної, фізичної, у санаторно-курортних умовах згідно із чинним законодавством [4].

Метою є отримання оптимального рівня боєздатності (працездатності) військовослужбовців, а також створення сприятливих умов для відновлення соціальної активності, розвитку й утвердження особистості; забезпечення оптимальних умов для повернення до нормальної життєдіяльності та роботи (військова служба).

Зважаючи на соціальну й економічну актуальність проблеми реабілітації військовослужбовців, ветеранів та інвалідів також, зокрема в санаторно-курортних умовах, відомчу неузгодженість, нестачу фінансування для оплати реабілітаційних послуг та фахівців для їх надання, відсутність чіткої державної політики та стратегії розвитку курортно-оздоровчих територій, актуальне розроблення механізмів публічного управління системою санаторно-курортної реабілітації військовослужбовців в Україні.

На рис. 1 представлені механізми публічного управління системою санаторно-курортної реабілітації військовослужбовців в Україні.

3-поміж інших механізмів публічного управління в цьому дослідженні нами розкрито ресурсний механізм, який складається зі структурно-технологічного, кадрового й інформаційного ресурсів.

У таблиці 1 узагальнено ресурси так званих «силових» відомств щодо надання послуг із санаторно-курортної реабілітації та СКЛ, організаційно-правові засади їх надання.

Окрім санаторно-курортних закладів, які перебувають у відомчому підпорядкуванні «силових» відомств, послуги із санаторно-курортної реабілітації та лікування військовослужбовцям надають також заклади, підпорядковані МОЗ України, Мінсоцполітики, приватні тощо.

Наприкінці 2018 р. було створено Міністерство у справах ветеранів України (Мінветеранів), яке є головним органом у системі центральних органів виконавчої влади, що забезпечує формування та реалізує державну

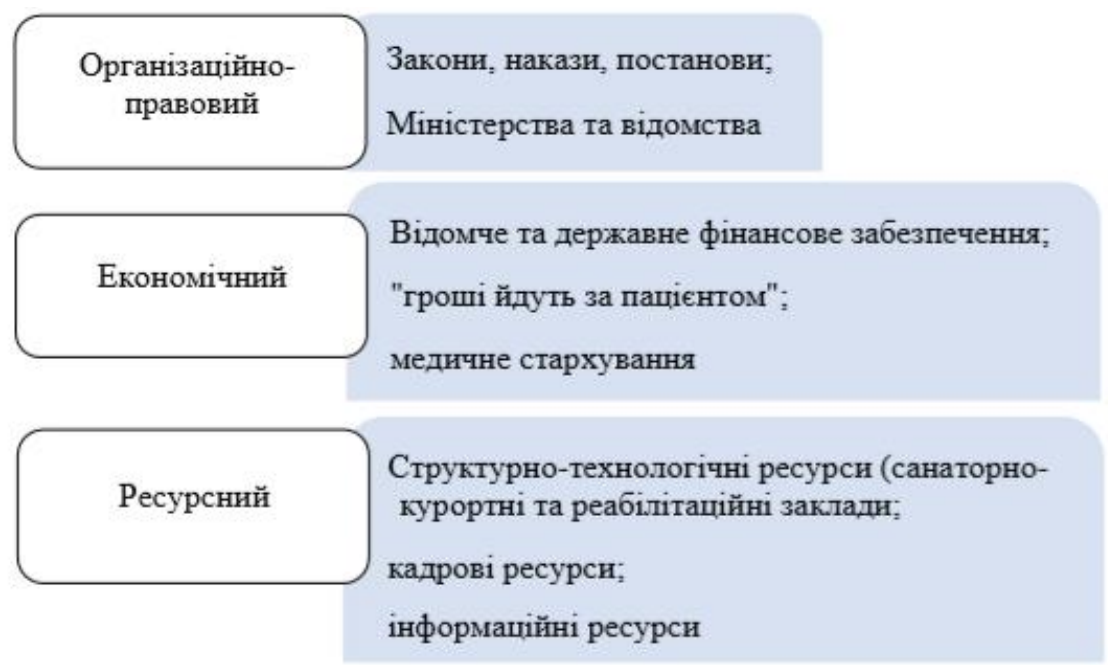

Рис. 1. Механізми публічного управління системою санаторно-курортної реабілітації військовослужбовців в Україні 
Забезпечення організації санаторно-курортного лікування військовослужбовців в Україні у відомчих санаторно-курортних закладах

\begin{tabular}{|c|c|c|}
\hline Відомство & Правове забезпечення & $\begin{array}{c}\text { Санаторно-курортні / } \\
\text { реабілітаційні заклади }\end{array}$ \\
\hline $\begin{array}{l}\text { Міністерство } \\
\text { оборони України }\end{array}$ & $\begin{array}{l}\text { Наказ Міністерства оборони України } \\
\text { від } 4 \text { листопада } 2016 \text { р. № } 591 \text { (зі змі- } \\
\text { нами, внесеними згідно } 3 \text { наказом } \\
\text { Міністерства оборони від } 17 \text { липня } \\
2018 \text { р. № 337) «Про затвердження } \\
\text { Інструкції про організацію санатор- } \\
\text { но-курортного лікування, медичної } \\
\text { та медико-психологічної реабілітації } \\
\text { у ЗСУ». }\end{array}$ & $\begin{array}{l}\text { - Центральний військовий санаторій } \\
\text { «Приморський»; } \\
\text { - центри медреабілітації та сана- } \\
\text { торного лікування «Пуща Водиця» і } \\
\text { «Трускавецький»; } \\
\text { - Центральний військовий клінічний } \\
\text { санаторій «Хмільник»; } \\
\text { - санаторій «Одеський» (колишній } \\
\text { «Лермонтовський»); } \\
\text { - санаторій у с. Затока. }\end{array}$ \\
\hline $\begin{array}{l}\text { Міністерство } \\
\text { внутрішніх } \\
\text { справ України та } \\
\text { Національна гвардія } \\
\text { України (далі - НГУ) }\end{array}$ & $\begin{array}{l}\text { Наказ МВС України «Про медичне } \\
\text { забезпечення в закладах охорони } \\
\text { здоров'я системи МВС України» від } \\
4 \text { листопада } 2003 \text { р. № } 1296 \text { (у редак- } \\
\text { ції від } 27 \text { січня } 2015 \text { р.). Наказ МВС } \\
\text { України «Про затвердження Порядку } \\
\text { пільгового реабілітаційного, СКЛ, } \\
\text { оздоровлення та відпочинку в медич- } \\
\text { них реабілітаційних центрах, сана- } \\
\text { торіях, будинках відпочинку, пансіо- } \\
\text { натах та оздоровчих закладах МВС } \\
\text { України поліцейських, деяких інших } \\
\text { категорій осіб та членів їх сімей» від } \\
14 \text { грудня } 2015 \text { р. № 1568. }\end{array}$ & $\begin{array}{l}\text { Санаторії МВС України: } \\
\text { - «Перлина Прикарпаття»; } \\
\text { - «Кременці»; } \\
\text { - «Миргород»; } \\
\text { - «Південний Буг»; } \\
\text { - Медичний реабілітаційний центр } \\
\text { «Затока». } \\
\text { Санаторії Національної гвардії } \\
\text { України: } \\
\text { - Медичний центр НГу «Нові } \\
\text { Санжари»; } \\
\text { - санаторій «Зелений мис» (Одеса), } \\
\text { передано до відомства, у стані рекон- } \\
\text { струкції. }\end{array}$ \\
\hline $\begin{array}{l}\text { Державна } \\
\text { прикордонна служба } \\
\text { України }\end{array}$ & $\begin{array}{l}\text { Наказ ДПС України «Про затвер- } \\
\text { дження Інструкції про організацію } \\
\text { санаторно-курортного } \\
\text { чення у ДПС України» від } 21 \text { черве- } \\
2011 \text { р. № } 444 .\end{array}$ & $\begin{array}{l}\text { - Клінічний санаторій «Аркадія» } \\
\text { (Одеса); } \\
\text { - санаторії «Моршин» та «Немирів» } \\
\text { (Львівська область), передано до ДПС } \\
\text { у 2016 р., у } \\
\text { стані реконструкції. }\end{array}$ \\
\hline $\begin{array}{l}\text { Служба безпеки } \\
\text { України }\end{array}$ & $\begin{array}{l}\text { Наказ СБу «Про затвердження } \\
\text { Інструкції про організацію санатор- } \\
\text { но-курортного забезпечення у СБУ» } \\
\text { від } 10 \text { квітня } 2017 \text { р. № } 202 \text { (зі змі- } \\
\text { нами від } 3 \text { січня } 2019 \text { р.). }\end{array}$ & $\begin{array}{l}\text { Санаторії: } \\
\text { - «Одеса»; } \\
\text { - «Трускавець»; } \\
\text { - «Ворзель». }\end{array}$ \\
\hline $\begin{array}{l}\text { Державна } \\
\text { служба України } \\
\text { з надзвичайних } \\
\text { ситуацій }\end{array}$ & $\begin{array}{l}\text { Наказ ДСНС «Про затвердження } \\
\text { Інструкції про організацію санатор- } \\
\text { но-курортного забезпечення у ДСН } \\
\text { України» від } 14 \text { листопада } 2016 \text { р. } \\
\text { № 1203. }\end{array}$ & $\begin{array}{l}\text { Медичний реабілітаційний } \\
\text { «Одеський». }\end{array}$ \\
\hline
\end{tabular}

Джерело: складено авторами за даними з офіційних сайтів

політику у сфері соціального захисту ветеранів. У його структурі функціонує Директорат реабілітації, медичного забезпечення та соціальної реадаптації ветеранів, відповідальний за надання послуг санаторно-курортного лікування та реабілітації. На етапі проєктування створення Мінветеранів планувалось передати в його відомче підпорядкування низку закладів охорони здоров'я, які надають послуги з медико-психологічної реабілітації ветеранам, зокрема госпіталі ветеранів війни: Український госпіталь для воїнів-інтернаціоналістів «Лісова поляна» (Київ), Львівський обласний госпіталь інвалідів війни та репресованих ім. Ю. Липи; санаторії ветеранів війни: «Перемога» (Київ),
«Батьківщина» (Трускавець), «Слава» (Миргород), «Салют» (Одеса) та Львівський міжрегіональний центр соціально-трудової, професійної та медичної реабілітації інвалідів [8]. На жаль, цього не було здійснено. Отже, Мінветеранів фактично $є$ розпорядником коштів, що передбачені Державною цільовою програмою з медичної, фізичної реабілітації та психосоціальної реадаптації на забезпечення санаторно-курортного лікування [9]. Згідно із принципом реалізації нової системи фінансування реабілітаційних послуг «гроші йдуть за пацієнтом», ветеранам надається можливість самостійного вибору санаторно-курортного або реабілітаційного закладу, укладається 
тристоронній договір між медичним закладом (надавач послуг), ветераном (особа, яка отримує послугу) та Мінветеранів (надавач коштів). Інформація щодо санаторно-курортних закладів, які надають послуги із СКЛ, розміщується на офіційному сайті Мінветеранів [10]: станом на 1 вересня 2020 р. це 107 закладів різної форми власності та відомчого підпорядкування, зокрема і приватні [11].

На сайті Міністерства соціальної політики України в розділі «Інвалідність - Реабілітація осіб 3 інвалідністю» розміщено інформацію щодо реабілітаційних установ сфери управління Міністерства й органів соціального захисту населення державної та комунальної форми власності, у яких надаються послуги з комплексної реабілітації (абілітація) відповідно до постанови КМУ від 31 січня 2007 р. № 80 [12]. Це реабілітаційні установи комунальної та державної форм власності. Зокрема, з переліку 147 закладів (станом на 1 січня 2019 р.) лише 8 - державні центри комплексної реабілітації осіб з інвалідністю, перебувають у відомчій підпорядкованості Мінсоцполітики (із них 3 - для дітей), а з-поміж інших лише половина надають послуги з комплексної реабілітації, зокрема майже 2/3 - дітям.

Міністерство охорони здоров'я України надає інформацію щодо можливості демобілізованим учасникам АТО/ООС пройти комплексну реабілітацію - медичну, фізичну та психологічну - у мережі госпіталів ветеранів війни [13]. Госпіталі ветеранів війни функціонують в системі МОЗ України, налічується 30 госпіталів на 6517 ліжок, розташованих у всіх областях країни. За період реформування медичної галузі вони були реорганізовані в комунальні неприбуткові підприємства. У 2015 р. обласні госпіталі ветеранів війни було визначено територіальними центрами реабілітації учасників АTO [14]. За результатами узагальнення досвіду роботи 19 госпіталів ветеранів війни України було розроблено модель організації медико-соціальної реабілітації учасників АТО з інвалідністю [15].

Підготовка кадрових ресурсів для системи санаторно-курортної реабілітації здійснюється в закладах вищої освіти Міністерства освіти і науки України, сумісно з МОЗ України. Наказом МОЗ України «Про внесення змін до Довідника кваліфікаційних характеристик професій працівників. Випуск 78 «Охорона здоров'я»» для розвитку реабілітаційної служби України та узгодження її із сучасними стандартами у 2016 р. були запроваджені нові спеціальності: лікарська (лікар фізичної та реабілітаційної медицини) та нелікарські (ерготерапевт, фізичний терапевт) [16].
Медична допомога здійснюється мультидисциплінарною командою залежно від наявної патології. Так, наприклад, медико-психологічна реабілітація посттравматичного стресового розладу (далі - ПТСР) здійснюється фахівцями санаторно-курортних закладів за участю лікаря психіатра, лікаря-психотерапевта, лікаря-психолога, психолога, практичного психолога й інших відповідних фахівців. До надання допомоги залучаються волонтери, ветерани-комбатанти, соціальні працівники, члени родин пацієнтів [17], медична допомога надається за Уніфікованим протоколом [18].

Під науково-методичним керівництвом ДУ «Український науково-дослідний інститут медичної реабілітації та курортології МОЗ України» створено низку відділень ранньої медичної реабілітації в санаторно-курортних закладах різної форми власності та відомчого підпорядкування, зокрема «силових» відомств. Розроблено показання та протипоказання щодо спрямування на медичну та медико-психологічну реабілітацію, науково обґрунтовані методи лікування, які засновано на поєднаному застосуванні природних лікувальних ресурсів та фізичних лікувальних чинників, зокрема ПТСР, розкрито склад мультидисциплінарної реабілітаційної команди [19]. СКЛ здійснюється згідно зі Стандартами [20], які нині потребують оновлення.

Висновки. Основними проблемами організації санаторно-курортного лікування та реабілітації військовослужбовців в Україні $€$ міжвідомча неузгодженість; значна розгалуженість санаторно-курортних та реабілітаційних закладів, які надають цей вид медичної допомоги, що ускладнює їхню підзвітність і аналіз ефективності лікування; відсутність єдиних стандартів та необхідність оновлення чинних стандартів надання медичної та медико-психологічної допомоги в санаторно-курортних умовах.

Вирішення питань публічного управління системою медичної (психологічна, фізична) реабілітації та санаторно-курортного лікування військовослужбовців сприятиме впровадженню в національне законодавство міжнародних стандартів у сфері реабілітації, удосконаленню системи надання реабілітаційних послуг (фізична, медична, психологічна реабілітація) на етапі санаторно-курортного лікування та розвитку системи реабілітації в Україні, зниженню рівня інвалідизації військовослужбовців та скорішому поверненню до військової служби, покращенню якості їхнього життя, відновленню залишкової працездатності ветеранів та поверненню їх до активного соціального та професійного життя. 


\section{ЛІТЕРАТУРА:}

1. Про чисельність Збройних Сил України : Закон України від 5 березня 2015 р. № 235-VIII. URL: https://zakon.rada.gov.ua/laws/show/235-19\#Text.

2. Укрінфрорм : офріційний вебсайт. 18.09.2019. URL: https://www.ukrinform.ua/rubric-ato/2782328v-ukraini-majze-370-tisac-ucasnikiv-bojovih-dij. html\#: :text.

3. Мойса Б. Реабілітація жертв конфрлікту. Чи пропонує держава щось, крім встановлення інвалідності та милиць? / за ред. О. Павліченка, О. Мартиненка. Українська Гельсінська спілка з прав людини. Київ, 2018. 64 c.

4. Про соціальний і правовий захист військовослужбовців та членів їх сімей : Закон України від 20 грудня 1991 р. № 2011-XII (зі змінами від 3 липня 2020 p. № 720-IX). URL: https://zakon.rada.gov.ua/ laws/show/2011-12\#Text.

5. Про Річну національну програму під егідою Комісії Україна - НАТО на 2020 р. : Указ Президента України від 26 травня 2020 р. № 203/2020. URL: https://zakon.rada.gov.ua/laws/show/203/2020\#Text.

6. Медичне забезпечення антитерористичної операції: науково-організаційні та медико-соціальні аспекти : збірник наукових праць / за заг. ред. В. Цимбалюка, А. Сердюка. Київ : ДП «НВЦ «Пріоритети», 2016. 316 с.

7. Про затвердження Порядку забезпечення санаторно-курортними путівками до санаторно-курортних закладів військовослужбовців, ветеранів війни, ветеранів військової служби, органів внутрішніх справ та деяких інших категорій осіб і членів їх сімей : постанова КМУ від 27 квітня 2011 р. № 446 (редакція від 16 травня 2017 р.). URL: https://zakon.rada.gov.ua/laws/show/446-2011\%D0\%BF\#Text.

8. Проєктний офріс зі створення Міністерства у справах ветеранів України робочої групи Комітету Верховної Ради України у справах ветеранів, учасників бойових дій, учасників антитерористичної операції та людей з інвалідністю. URL: https://legal100.org.ua/ wp-content/uploads/2018/11/Prezentatsiya_MinVet.pdf.

9. Про затвердження Державної цільової програми 3 медичної, фрізичної реабілітації та психосоціальної реадаптації постраждалих учасників Революції Гідності, учасників антитерористичної операції та осіб, які брали участь у здійсненні заходів із забезпечення національної безпеки і оборони, відсічі і стримування збройної агресії Російської Федерації в Донецькій та Луганській областях, забезпеченні їх здійснення, на період до 2023 р. : постанова Кабінету Міністрів України від 5 грудня 2018 р. № 1021. URL: https://zakon.rada.gov.ua/laws/show/1021-2018\%D0\%BF\#Text.
10. Міністерство у справах ветеранів Україні : офріційний вебсайт. URL: https://mva.gov.ua/ua/veteranam/ likuvannya-ta-reabilitaciya/sanatorno-kurortnelikuvannya.

11. Радиш Я., Соколова О. Медична реабілітація українських військовослужбовців, що постраждали в результаті бойових дій (до проблеми державного регулювання системи санаторно-курортного забезпечення військовослужбовців Збройних сил України). Інвестиції: практика та досвід. 2014. № 24. C. 152-155. URL: http://nbuv.gov.ua/UJRN/ ipd_2014_24_32.

12. Міністерство соціальної політики України : ооріційний вебсайт. URL: https://www.msp.gov.ua/news/ 8361.html.

13. Куди звертатися ветеранам АТО/ООС для реабілітації. 25 жовтня 2018 р. Міністерство охорони здоров'я України : офріційний вебсайт. URL: https://moz.gov.ua/article/health/kudi-zvertatisjaveteranam-atooos-dlja-reabilitacii.

14. Гавловський О. Організація фрізичної та психологічної реабілітації учасників антитерористичної операції в Україні. Вісник проблем біології і медицини. 2019. Вип. 2. Т. 1 (150). С. 275-279.

15. Модель організації медико-соціальної реабілітації учасників АТО 3 інвалідністю : методичні рекомендації / укл. : В. Шевчук та ін. Вінниця: ФОП Рогальська І.О., 2018. 32 с.

16. Про внесення змін до Довідника кваліфікаційних характеристик професій працівників. Випуск 78 «Охорона здоров'я»: наказ Міністерства охорони здоров'я України від 7 листопада 2016 р. № 1171. URL: https://zakon.rada.gov.ua/rada/ show/v1171282-16\#Text.

17. Проблемні питання психологічної реабілітації ветеранів учасників антитерористичної операції та військовослужбовців операції об'єднаних сил в Україні : аналітичний огляд літератури / І. Назаренко та ін. Україна. Здоров'я нації. 2019. № 1 (54). С. 48-58.

18. Уніфікований клінічний протокол первинної, вторинної (спеціалізованої) та третинної (високоспеціалізованої) медичної допомоги «Реакція на важкий стрес та розлади адаптації. Посттравматичний стресовий розлад» : наказ МО3 України від 23 лютого 2016 p. № 121. URL: https://dec.gov.ua/wp-content/ uploads/images/dodatki/2016_121_PTSR/2016_121_ YKPMD_PTSR.pdf.

19. Реабілітація постраждалих в умовах надзвичайних ситуацій та бойових дій. Посттравматичний стресовий розлад : монографрія / за ред. К. Бабова, І. Пінчук, В. Стеблюка. Одеса : Поліграф, 2015. 240 с.

20. Стандарти (клінічні протоколи) санаторно-курортного лікування / за заг. ред. М. Лободи та ін. Київ : КІМ, 2008. 416 с. 